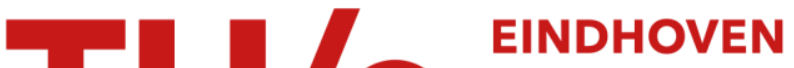

\section{Stereochemical selection in phosphoranyl radical formation using ionization radiation}

\section{Citation for published version (APA):}

Janssen, R. A. J., Aagaard, O. M., Woerd, van der, M. J., \& Buck, H. M. (1990). Stereochemical selection in phosphoranyl radical formation using ionization radiation. Phosphorus, Sulfur and Silicon and the Related Elements, 51(1-4), 758-. https://doi.org/10.1080/10426509008040822

DOI:

10.1080/10426509008040822

Document status and date:

Published: 01/01/1990

\section{Document Version:}

Publisher's PDF, also known as Version of Record (includes final page, issue and volume numbers)

\section{Please check the document version of this publication:}

- A submitted manuscript is the version of the article upon submission and before peer-review. There can be important differences between the submitted version and the official published version of record. People interested in the research are advised to contact the author for the final version of the publication, or visit the $\mathrm{DOI}$ to the publisher's website.

- The final author version and the galley proof are versions of the publication after peer review.

- The final published version features the final layout of the paper including the volume, issue and page numbers.

Link to publication

\section{General rights}

Copyright and moral rights for the publications made accessible in the public portal are retained by the authors and/or other copyright owners and it is a condition of accessing publications that users recognise and abide by the legal requirements associated with these rights.

- Users may download and print one copy of any publication from the public portal for the purpose of private study or research.

- You may not further distribute the material or use it for any profit-making activity or commercial gain

- You may freely distribute the URL identifying the publication in the public portal.

If the publication is distributed under the terms of Article 25fa of the Dutch Copyright Act, indicated by the "Taverne" license above, please follow below link for the End User Agreement:

www.tue.nl/taverne

Take down policy

If you believe that this document breaches copyright please contact us at:

openaccess@tue.nl

providing details and we will investigate your claim. 


\section{STEREOCHEMICAI SELECTION IN PHOSPHORANYI RADICAI FORMATION USING IONIZING RADIATION}

\section{R.A.J.JANSSEN, O.M.AAGAARD, and H.M.BUCK Department of Organic Chemistry, Eindhoven Universi- ty of Technology, P.O.Box 513, 5600 MB Eindhoven, The Netherlands}

Recent electron spin resonance (ESR) experiments on phosphorus-centered radicals generated by ionizing radiation demonstrate that stereochemical aspects act strongly on the rate of radical formation and can be decisive in the selection between the possible resulting radical structures. This phenomenon was first established in a single crystal ESR study on radiogenic electron-capture phosphorus-centered radicals of the racemic and meso stereoisomers of 1,2-dimethyl-1,2-diphenyldiphosphine disulfide (1). The radiation process of the racemic form involves the formation of a symmetric species with a three-electron bond in an overall low yield. The meso isomer, on the other hand, yields exclusively asymmetric radical configurations in which the unpaired electron resides on one of the two phosphorus nuclei. The high intensity of the ESR spectra for the meso compound indicate a more efficient electron-capture process. A similar pronounced difference in radiosensitivity was observed for the $R_{P}(1)$ and $S_{P}(2)$ isomers of $(4 S, 5 R)$ 2-chloro-3,4-dimethy1-5-phenyl-1,3,2-oxazaphospholidine 2-sulfide. Upon $X$ irradiation, 1 readily results in an electron-capture phosphorus centered radical, whereas the concurrent process in 2 is almost completely absent. Since the geometric parameters of the atoms directly linked to phosphorus are very much alike for 1 and 2 it can be concluded that the efficiency of electron-capture at phosphorus strongly depends on the relative configuration of the distant chiral centers at $C_{4}$ and $C_{5}$.<smiles>CC1C(c2ccccc2)O[P@@](Cl)(SS)N1C</smiles><smiles>CC1C(c2ccccc2)OP(=S)(Cl)N1C</smiles>

(1) R.A.J. Janssen, M.J. van der Woerd, O.M. Aagaard, H.M. Buck, J. Am. Chem. Soc. 110, 6001 (1988). 